\title{
Lebende Sprachen
}

\section{Zeitschrift für fremde Sprachen in Wissenschaft und Praxis zugleich Fachblatt des Bundesverbandes der Dolmetscher und Übersetzer e.V. (BDÜ) Begründet von Alexander Lane Herausgegeben von Günther Haensch und Friedrich Krollmann}

XXXIX. Jahrgang 1994

Heft 3

3. Vierteljahr 1994

\section{Inhalt}

U. REINKE: Zur Leistungsfähigkeit integrierter Übersetzungssysteme .................. 97

A. SCHREITMÜLLER: Interlinguale Relationen ... 104

W. FrIEDERICH: Was ist ein „Production Dictionary"? ......................... 107

Englisch

P. PEETERS: Digitale Vermittlungsstellen (E-D) 109

J. BARTSCH: Was noch nicht im Wörterbuch steht: Lebensmittel (E-D) .............. 113

P. NEWMARK: Sexist language in translation .... 114
Französisch

D.J.M. SOULAS DE Russel: Glossaire des monnaies du monde (F-D) ............... 115

U. STÖMMER: Zahnärztliche Instrumente (D-F) 119

Spanisch

G. HAENSCH: Was noch nicht im Wörterbuch steht (S-D) ....................... 121

F. RodríGueZ GonZÁLEZ: Glossary of Drug-Related Slang $(\mathrm{E}-\mathrm{S}) \ldots \ldots \ldots \ldots \ldots \ldots \ldots \ldots, 123$

Mehrsprachige Beiträge

H. ZERWES: Zollkodex der Gemeinschaft (Teil II) (D-E-F-S) ................ 125

Terminologiedienst ................. 136

Briefe an die Herausgeber ............. 138

Fachliteratur ....................... 138

Rezensionen ........................... 139

Umschau $\ldots \ldots \ldots \ldots \ldots \ldots \ldots \ldots \ldots \ldots .140$

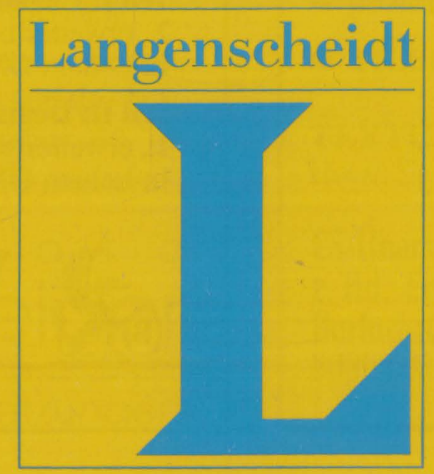




\section{La ruta del bakalao}

Ultimamente aparece con frecuencia en la prensa española una expresión nueva: la ruta del bakalao (y los que la toman son los bakaladeros). Esta ruta, que lleva principalmente a Valencia, es la ruta de la muerte para los jóvenes entre 17 y 26 años que, dopados con "speed" u otras drogas, alcoholizados y transnochados conducen con exceso de velocidad. En noviembre del año 1993, hubo en una noche 15 muertos en tres ciudades españolas. Para más información de nuestros lectores reproducimos una nota aparecida en la revista “Carta de España" (No. 476, diciembre de 1993, pág. 7)

\section{La ruta del bakalao}

Hay más de una, aunque la principal conduce a Valencia, a las macro-discotecas de la periferia. La "ruta del Bakalao" es una peregrinación nocturna, de fin de semana: cientos de jóvenes, y maduritos, se lanzan a la carretera para llegar a esos "santuarios", donde se empapan de música atronadora, alcohol y. drogas. Después, en la madrugada, al coche: muchos, en acto final, abrazan la muerte. La Policía y otras fuerzas de Seguridad tratan de poner cerco a las "rutas de Bakalao", para reducir la siniestralidad: realizan controles de alcoholemia (no disponen de equipos para detectar alucinógenos en la sangre), practican identificaciones, proceden a detenciones. Su actuación ha conseguido reducir el número de fallecidos durante los fines de semana, aunque no logran acabar con el problema; porque, posiblemente, el problema no tiene solución. $\mathrm{El}$ "bakalao" parece una alternativa, no se sabe muy bien a qué.

\section{Glossary of Drug-Related Slang (E-S)}

The present glossary does not attempt to be a combined glossary of English and (European) Spanish drug terminology as such, but rather a list of correspondences between the two languages. The list is nearly exhaustive but I have intentionally left out some terms that are too obvious (like drug, droga) or too specialized and technical (alkaloid, alcaloide), and those that have an indirect relation to the subject (for example flora terms, such as pita, a plant from which certain drugs are extracted). Nor have I compiled terms that show differences in their denotative meanings, such as English earth (marijuana cigarette) and Spanish tierra (bad quality hashish), although I have included a few for which we may postulate some direct influence.

Most of the items included here are caracterized as being informal and colloquial (slang) rather than technical (jargon). Because of their peculiarity, I have attempted to give a translation that preserves the same or similar connotational meaning, for which reason $I$ have often avoided using the standard term except in the definition.

The correspondence and equivalence between the terms found was often produced as a result of a borrowing process since most of the Spanish terms are anglicisms which have been introduced through morphological adaptation (E. business $\rightarrow \mathrm{Sp}$. bisnes) and above all, through translation and semantic calque (E. China white $\rightarrow$ E. blanca china). At times a close cultural equivalent is needed, for example, tea is 'marijuana' in England, a nation where the tea beverage is very popular, but it is best rendered in Spanish by tila and manzanilla, which are common amongst us and show very similar associations.

For the definitions as well as the compilation of the terms I have consulted the following sources: For the English items, E. L. Abel, A Dictionary of drug abuse terms and terminology, Greenwood Press, 1984), Richard A. Spears, The slang and jargon of drugs and drink (Metuchen, N. J. \& London: The Scarecrow Press, 1986), J. Green, Neologisms since 1960 (Bloomsbury, 1991). For the Spanish items: Juan Oliver, Diccionario de argot (Barcelona: Sena, 1987), Víctor León, Diccionario de argot español (Madrid, Alianza, 1984) J. García Ramos: "El drogata", in El lenguaje actual de los maleantes españoles, I, Informe monográfico No. 8 (Policía, 1985, p. 22), "Argot empleado en el mundo de las drogas", en Saber ser mujer, pp. $122-23$, in addition to various journalistic sources.

abstinence syndrome 'withdrawal reaction from a drug': m. síndrome de la abstinencia.

acid 'lysergic acid diethylamide, L.S.D.' (The same term has been in use, especially in adjectival form, since the $1960 \mathrm{~s}$ to describe Ecstasy): m. ácido, L.S.D.

acid party 'a party or gathering in which a lot of acid and other illegal drugs are consumed': f. fiesta acid.

acid house: 'a style of music that blends house music with the drug Ecstasy': $m$. acid house, house.

addict 'person who is given up to the habit of consuming drugs': $\mathrm{m}$. adicto, toxicómano.

addiction: f adicción, toxicomanía

afghani 'potent hashish or marijuana from Afghanistan': m. afgano. amp 'short for amphetamine': f. anfeta (short for anfetamina). angel dust 'synthetic heroin; P.C.P. or phencyclidine': $m$. polvo de ángel.

Angola black 'a potent black variety of marijuana from Angola': angoleña. asscache (or asskash) 'a supply of drugs concealed in a capsule hidden in the rectum of a smuggler to avoid control by the police when passing through customs': $\mathrm{m}$. costo culero.

bad trip 'unpleasant drug reaction, for example, panic and anxiety. Generally associated with LSD, but also with other drugs': m. mal viaje.

bar 'compressed block of marijuana or hashish stuck together with sugar or honey': f. barra, barrita.

Bible 'a book of cigarette papers': $\mathrm{f}$. biblia

blind adj. phr. to be blind 'alcohol or drug intoxicated': ciego (n.) phr. ponerse ciego, llevar o coger un ciego.

blotter (also blotter acid, blot) 'absorbent paper in which LSD solution has been placed': $\mathrm{m}$. secante, sello.

business 'the drug-selling business': m. bisnes, bisne, bisni, trapicheo.

Californian sunshine: 'LSD; variety of LSD': m. californiano.

candy 'drugs in general; specific drug: hashish, L.S.D. (Used specifically for L.S.D. when referring to a sugar cube impregnated with a drop of the substance)': $m$. caramelo.

carrying, posession (of drugs) 'having drugs in one's immediate possession': f. posesión.

China (or Chinese) white: 'Pure or nearly pure heroin which is more accessible and cheaper than the normally available heroin and can be sniffed or smoked, which is why it has been welcomed by cocaine users'. Also called synthetic heroin: f. blanca china.

chocolate 'hashish': chocolate (also used in abbreviated and diminutive forms: tate, choco).

chop 'to finely divide a drug': v. picar.

coke 'abrev. of cocaine': f. coca (abbrev. of cocaina).

cokey, cokie 'a cocaine user; a cocaine addict': coquero, - $a$ (cocainómano).

cold turkey (phr. "to go cold turkey, take the cold turkey") "having to do with a sudden and complete withdrawal from addictive drugs': pavo (phr. "estar con el pavo, estar de pavo").

Colombian gold, Colombo 'gold-colored marijuana from Colombia': colombiana (The $\mathrm{Sp}$. term has been attested in reference to cocaine).

come down 1. v. 'for a drug user to experience the waining of a drug's effects': bajar . 2. n. (also spelled comedown) 'final effects of a drug experience, often involving depression': f. bajada.

conga, Congo (also in the phrases Congo brown, Congo dirt) 'varieties of marijuana from Central Africa': congo.

connection 'a drug distribution ring': f. conexión, connection (Generally the English form connection is preferred in Spanish).

cotton 'a pice of cotton used to strain a liquid drug when filling a syringe for an injection': m. algodón.

courier 'a small-time drug seller; a drug runner' (cf. mule): m. correo (The $\mathrm{Sp}$. term is used to designate the person who moves drugs in small quantities form one country to another).

crack 'a purified and potent form of cocaine which is smoked rather than snorted': m. crack.

crap 'drug in general': f. mierda.

cut (also cut up) 'to dilute drugs': v. cortar. cf. chop.

deal 'to traffic in drugs; to sell drugs on the retail (street) level': v. camellear, dilear, bisnear.

dealer 'a drug seller or supplier' (cf. pusher): m. díler, traficante.

designer drug 'a type of synthetic heroin': f. droga de diseño.

dex (also dexies, dexo) 'abrev. of dexedrine, a potent amphetamine': f. dex (dexedrina) 
dope v. 'to take drugs': dopar (drogar). Sp. dopar is often used in sports, especially in the form doping.

doped up (also doped): adj. dopado, drogado.

doping 'Use of drugs to improve an individual's performance': $\mathrm{m}$. doping, dopaje.

drop 'an oral dose of a drug (used mainly in reference to L.S.D.': $f$. gota (liquid variety of L.S.D.).

druggie (also druggy) 'a drug user'; an addict': drogata, drogui. dust, powder 'powdered drug (cocaine, heroin, morphine)': $\mathrm{m}$ polvo.

dynamite 'a powerful powder drug': f. dinamita.

eater 'narcotics user who takes his drugs orally': In Spanish the form attested is a verb, comer.

Ecstasy (also called love drug) 'a kind of designer drug which results in a growing confidence in oneself and a greater ease in communicating with people': éxtasis (also called droga del amor).

euphoriant 'drug causing euphoria': adj. euforizante.

fix 'an injection of narcotics': $m$. fix, fise, pico.

flash 'sudden feeling of euphoria from intravenous injection of heroin': m. flash, flas, pelotazo, subidón, f. coz.

flip out (also flip): 'to have an unpleasant experience following marijuana use, or conversely, to have an enjoyable reaction: $v$. flipar, fliparse (The Sp. term flipar is often used figuratively with the meaning of 'to charm': „ese vestido me flipa“).

flipped 'stupefied by drugs: drug intoxicated': adj. flipado, flipao (cf. colocado, drogado; the Sp. term is often used figuratively with the meaning of 'surprised, engrossed with something').

floating, flying 'drug intoxicated': cf. (estar) volado, flotar.

fly 'to take drugs; to be high on drugs': v. volar.

glue 'glue products containing aromatic hydrocarbons such as toluene which are sniffed': m. pegamento.

going high 'a long-lasting type of drug high': cf. Sp. v. subir.

Golden triangle 'an area at the boundaries of Burma, Laos and Thailand considered to be a paradise for heroine users and traffickers': m. triángulo de oro.

grass 'marijuana (the most popular term for marijuana in the 1960s)': f. hierba.

greefa (also spelled grifa, griffa, griffo, grifo): f. grifa, marijuana (The Spanish term grifa is often used in reference to the marijuana coming from Africa).

greefer 'a marijuana smoker': grifota.

gum (or goma hashish) 'good-quality hashish of a chewy consistency': f. goma, gometa, gomita, goma de Oklahoma.

guru' an experienced L.S.D. user who coaches someone through an L.S.D. trip': m. gurú.

hard drugs 'addictive drugs: heroin, morphine, cocaine, opium': f. drogas duras.

harpoon 'needle used for narcotics injection': m. arpón

hashish 'the resin of the female marijuana plant; marijuana with a very high resin content (also used as a synonym of marijuana)': $\mathrm{m}$. hachis (sometimes also spelled hashish, hachish)

hemp 'marijuana; cannabis' (It is the common name for the marijuana plant): m. cáñamo.

high (adj. phr. "to be (in) high") "under the pleasurable effects of marijuana or other drugs': adj. alto (phr. "estar alto").

hooked 'physically dependent on drugs (usually referred to heroin)' adj. enganchado.

horse 'heroin': m. caballo, jaco, potro.

penthotal, used by police as "truth serum": m. pentotal, "inyección de la verdad".

hot 'carrying drugs and subject to arrest': $\mathrm{cf}$. Sp. phr. dinero caliente: 'money obtained through selling drugs'.

hung up 'addicted to a drug; having a hang-up about a drug' (cf. hooked): colgado (cf. enganchado)

joint 'a marijuana cigarette' (also called bomb, bomber, dynamiter, dynamite, torpedo, sausage: m. porro, joint (pron. yoe, yoin; joe, join). Also called petardo, canuto.

junkie (also junkey, junkie) 'a drug addict especially one addicted to heroin' (from the word junk 'addictive drug; heroin'): yonqui (also spelled yonky, junki, junkie, yunqui, yunki).

lady 'cocaine': f. lady.

launder (money coming from drugs): lavar, blanquear.

laundering (of money coming from drugs): lavado, blanqueo.

line 'a dose of chopped cocaine or any powdered drug ready to be snorted': f. línea, raya.

magic mushrooms 'mushrooms of the genus Psylocybe which cause hallucinations when eaten': $m$. hongo mágico.

mainline 1. $\mathrm{n}$. 'the median cephalic vein (in the forearm), the favored site for intravenous injections' (cf. pipe): f. tubería. 2. v. 'to inject a drug intravenously' (cf. shoot): picarse.

Mary 'short for marijuana': f. maría.

merchandise 'drugs': f. mercancía (sometimes abbreviated to merca)

microdot 'a small portion (microgram) of L.S.D. on a tablet or on blotting paper': $\mathrm{m}$. micropunto.

monkey (phr. "to have a monkey on one's back) 'drug addiction' mono (phr. "estar con el mono")

morph (also morf, morphi, morpho, mophy) 'abbrev, of morphine, a powdered drug': morfa.

mother 'marijuana': madre.

move 'to traffic in marijuana; to sell drugs': mover.

mule 'someone who delivers or smuggles drugs for a dealer: $\mathrm{m}$. correo (Hispanics in the United States use mula).

narcotic 'a sleep inducing, pain-relieving substance; any illegal or addictive drug substance': m. narcótico, estupefaciente.

oil 'an alcohol extract of hashish': $m$. aceite

orange 'an orange tablet impregnated with L.S.D.': m. orange

paper 1 . 'cigarette rolling paper': $\mathrm{m}$. papelillo (papel de fumar); 2 . 'a folded paper containing a dose of powdered drugs': f. papela papelina.

paper boy 'a heroin dealer': $\mathrm{m}$. papelinero.

pass 'a succesful drug sale': $\mathrm{m}$. pase (In Sp. the term is more often used idiomatically with a different meaning: darse el pase, darse pases 'to inhale cocaine').

passed out 'unconscious as a result of drug used': (estar) pasado.

peddler 'a seller of drugs, usually on the retail (street) level': $\mathrm{m}$. camello (The Sp. word camello was originated through association with a camel, an animal considered to be a typical beast of burden in Africa, from where the most popular drug (greefa) in the seventies came into Spain).

Peruvian flake 'high quality cocaine from Peru': f. peruana.

pill 'an amphetamine tablet': f. pilula.

pinch 'a small amount of marihuana or snuff': m. pellizco.

pipe, sewer 'large vein into which the drug is injected': f, tubería, cañería, macarrón

poke 'inhalation of a drug cigarette': f. calada, recalada.

psychoactive adj. psicoactivo, psicotrópico.

psychotropic adj. psicotrópico, psicoactivo.

pump up 'to bring up a vein for injection by making a fist repeatedly': v. bombear.

pusher 'drug seller (usually used in reference to narcotics, especially heroin, whereas dealer is a term used to refer to a seller of 'soft' drugs, especially marihuana. It also designates a drug dealer who works hard to establish new addicts and customers)': $\mathrm{m}$. púcher, traficante.

resin 'the sticky substance found predominantly in female cannabis plants': f. resina.

roach (from cockroach) 'the butt end of marijuana cigarette)' cucaracha (The terms chicharra, chicharrita are also used in Sp. but they apply also to nondrug cigarette ends).

rock 'a chrystallized form of cocaine (often used in reference to crack': f. roca.

roll (up) a cigarette: liar, armar (preparar un cigarrillo, porro, etc.) shit 'drugs in general; a specific drug: hashish, heroin or marijuana': f. mierda (used especially in reference to hashish).

shoot (also shot) 1. n. 'an injection of heroin': chute. 2. v. 'to inject a specific drug into the bloodstream; to take a dose of drugs by injection': chutarse (also ponerse un chute, hacer un chute, tirar de chuta; cf. también picarse, pincharse, meterse un pico, meterse un buco)

shooting gallery 'place where narcotics users get together to inject themselves or be injected': f. galería de tiro.

sniff 'to inhale cocaine or heroin through the nose': snifar, esnifar. sniffer 'a drug user who habitually takes cocaine or heroine nasally' esnifador, $a$.

snorter: 'device used for sniffing cocaine': m. esnifador

snow (also flake) 'a white drug, preferably cocaine': f. nieve.

soft drugs 'nonadditive drugs such as marijuana, hashish, amphetamines': f. drogas blandas.

spear (also spike) 'hypodermic needle': lanza (also known as chutosa, picona, pico)

speed 1. n. 'amphetamine': m. speed (or espid). 2. v. 'to be high on amphetamine': espitar, estar espitoso.

stoned adj. 'alcohol or drug intoxicated': colocado.

stuff 'drug in general': m. material

superman 'a kind of L.S.D.': m. supermán.

talcum powder 'bogus powdered drugs': $\mathrm{m}$. talco (The $\mathrm{Sp}$ term has been attested with the meaning of heroin).

tea 'marijuana': f. tila, manzanilla.

trafficker 'drug seller': traficante (de drogas).

traveller, voyager, tripper 'an LSD user; a drug user': m. viajero.

trip 1. 'a high from a hallucinogenic drug LSD': trip, viaje (The term trip in Spanish is also used in reference to the dose of LSD or acid).

2. v. 'to experience an LSD high or trip': v. intr. tripar, tripear, viajar, volar, hacer un viaje.

Turk dope: 'heroin derived from Turkish-grown poppies': turca. twenty-five 'LSD': veinticinco.

vibrations (also used in the clipped form vibes) 'feelings concerning someone or something': f. pl. vibraciones.

white 'powdered drug: cocaine, heroin': f. blanca

white powder 'powdered drug': polvo blanco. (See white) 